\title{
The Role of Human Capital in Economic Growth in Coastal Provinces of Southern Central Vietnam
}

\author{
Hạ Thị Thiều Dao \\ Banking University HCMC - daohtt@buh.edu.vn \\ Nguyễn Đăng Khoa \\ Bình Thuận Community College - nguyenkhoa.pt@btu.edu.vn
}

\begin{tabular}{ll} 
ARTICLE INFO & ABSTRACT \\
\hline $\begin{array}{l}\text { Article history: } \\
\text { Received: }\end{array}$ & $\begin{array}{l}\text { To examine the role of human capital in economic growth in coastal } \\
\text { provinces of Southern Central Vietnam (SCV), the research employs } \\
\text { data from balance sheets of eight provinces in this region and a }\end{array}$ \\
$\begin{array}{c}\text { Received in revised form } \\
\text { Jan. 242014 }\end{array}$ & $\begin{array}{l}\text { neoclassical growth model with an extended Cobb-Douglas } \\
\text { production function including the following variables: output, } \\
\text { capital, labor, human capital and other macroeconomic variables that } \\
\text { have effects on economic development. The estimation results based } \\
\text { on the fixed effect model show that the economic growth is affected } \\
\text { June 302014 capital, labor, human capital, FDI, public expenditure, and }\end{array}$ \\
\hline $\begin{array}{l}\text { Keywords: } \\
\text { human capital, economic } \\
\text { growth, education, labor } \\
\text { quality }\end{array}$ & $\begin{array}{l}\text { agricultural production. Of this variable, the human capital is } \\
\text { represented by average schooling year of laborers with an estimated } \\
\text { effect of nearly 0.43\% per a one-percent increase in the average } \\
\text { schooling year. }\end{array}$
\end{tabular}




\section{PROBLEM STATEMENT}

Theoretically, human capital reflects qualitative and quantitative contribution from human labor to economic growth. Results of empirical researches, however, show a disagreement over tests for relationship between human capital and economic growth. UNDP (2011) confirms that "Health care and education are keys to human development" but "educational and health care progress is not always associated with increases in income." Permani (2009) demonstrates a causal relationship between human capital and economic growth while Leeuwen (2004) shows that this relationship is not clear. That is why Romer (1990) warns that explanation of correlations between human capital and economic growth requires a great caution because mutual effects, instead of a one-way relationship, may exist between increases in output and increases in human capital.

In the years 2000-2011, SCV coastal provinces gained a high average growth rate of $11.7 \%$ while the national average was 7.11\%. The report of 2011 Labor and Employment Survey (GSO, 2012) states that labor force participation rates in Northern Central Vietnam and coastal provinces of Central Vietnam are only second to those found in midland and mountainous regions in North Vietnam and Western Highlands. Whether or not a positive correlation exists between human capital and economic growth in SCV coastal provinces that experience the highest frequency of natural disasters is the question this research tries to answer in order to analyze the role of human capital and other factors in the economic growth of SCV coastal provinces in 2000-2011 and thereby offering solutions to development of growth factors and economic growth in general for this region as well as for the whole country.

\section{HUMAN CAPITAL AND ANALYTICAL FRAMEWORK}

Many theories and models confirm the role of human capital in the economic growth. The neoclassical growth theory with Solow model (1956) considers human capital as an input for economic growth. This theory, however, treats human capital as an exogenous variable and only focuses on its quantity. The endogenous growth theory developed by Lucas (1988) and Mankiw et al. (1992) consider human capital as a factor that affects directly the economic growth or impacts indirectly through technological replacement as suggested by Romer (1990) with his R\&D model.

Human capital is a complicated concept with reguard to human skills, knowledge, labor ability, health and human values that took shape during the lifetime of an individual through investment and accumulation processes, of which education is considered the most 
basic one. The OECD 2011 report defines human capital as "the knowledge, skills, competencies and attributes embodied in individuals that facilitate the creation of personal, social and economic well-being." Laroche (1999) suggests that human capital can be either general or specific, has qualitative as well as quantitative aspects, and can be influenced by external effects. It is also a non-tradable good (there exists no market that would permit the exchange of human capital assets), and individuals do not always control the channels and pace by which they acquire human capital.

Human capital, as a complicated concept, is also assessed by various measures: (i) literacy rates among adults (Romer, 1989), primary school enrollment rates (Barro, 1991), and junior high school enrollment rates (Mankiw et al., 1992); (ii) labor income (Mulligan \& Sala-i-Martin, 1997) as they argue that individuals' class is connected with wages they acquire from the market; (iii) average years of schooling of the labor force (Barro \& Lee, 1993) which has been widely applied by other researchers; (iv) cost of education used as a weight by Judson (1995) to calculate human capital stock for each level of education.

Although opinion is divided on the role of human capital in economic growth over countries, most empirical researches on the role of human capital in various regions or provinces in a country produce similar findings. Lau et al. (1993) and Cravo \& Soukiazis (2009) agree that long-term investment in development of education is needed for promoting economic growth in states of Brazil. Coulombe \& Tremblay (2001) state that education is the key to economic growth for many regions in Canada. Ng \& Leung (2004) suggest that expansion of tertiary education and improvement in quality of secondary education are main solutions for economic development in many Chinese provinces. Nguyễn \& Lê (2006) and Trần et al. (2007) maintain that investment in development of education is a feasible measure to enhance economic growth and development in Vietnam's provinces. Similar findings are also presented in researches by Galino Martin \& Herranz (2004), Permani (2008), Li \& Liang (2009), and Vidyattama (2010), etc.

Meanwhile, many researchers, such as Barro (1991), Mankiw et al. (1992), and Barro \& Sala-i-Martin (1995), etc. have also looked for non-human capital factors as determinants of economic growth for years. Some determinants that produce effects on provincial or regional economies of a country are:

(i) Investment representing physical capital of the economy affects positively the economic growth; 
(ii) Labor force as an indispensable factor of economic growth: Its quality is considered as a type of human capital while increases in its quantity or size support positively the economic growth;

(iii) Internationally economic integration, or trade openness: It is usually expressed as the ratio of the sum of exports plus imports to the GDP. Researches show that the trade openness has a positive impact on the economic growth;

(iv) Reasonable public expenditure may stimulate the economic growth but it may become a hindrance when it exceeds some rational limit (Rahn, 1986);

(v) Effects of state-owned enterprises: Ng \& Leung (2004), and Trần et al. (2007) argue that a poor performance could be found among state-owned enterprises, which reduces their contribution to the economic growth;

(vi) Diminishing share of agriculture in economic growth: $\mathrm{Ng} \&$ Leung (2004) show that expansion of non-farm activities is an important step toward economic growth.

The above-mentioned literature review allow authors to suggest an analytical framework as presented in Figure 1 with an emphasis on impacts of human capital on economic growth while effects of other factors are treated as control variables in the research.

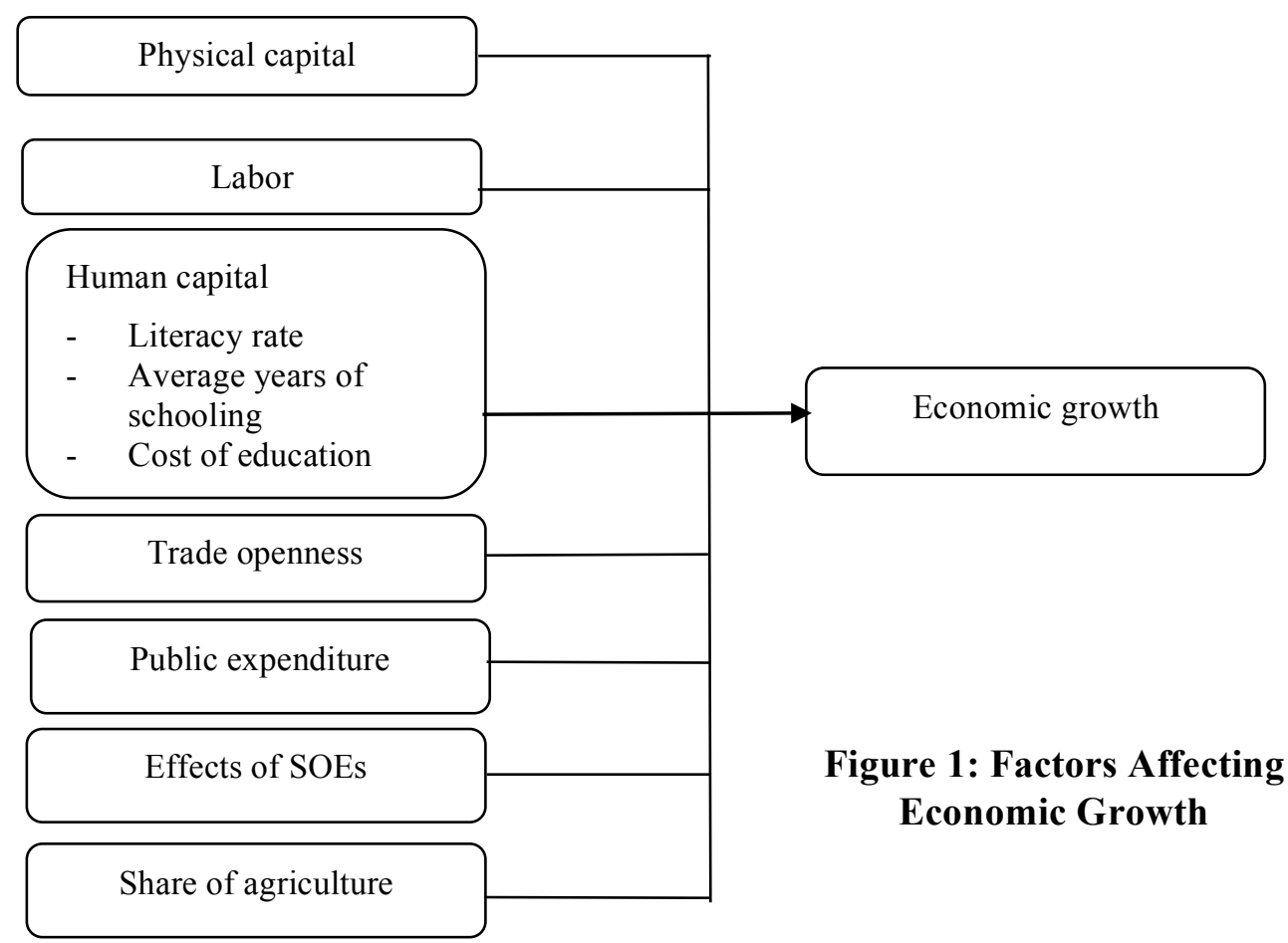




\section{RESEARCH MODEL AND VARIABLES}

After examining relevant theories and researches, especially the study by $\mathrm{Ng} \&$ Leung (2004), the authors suggests the following model based on Cobb-Douglas production function:

$$
Y_{i t}=A_{0} K_{i t}^{\beta_{K}} H_{i t}^{\beta_{H}} L_{i t}^{\beta_{L}} e^{\theta Z_{i t}+u_{i t}}, Z=(F, G, S O E, A R G) .
$$

Where:

i: city/province

t: time

$\mathrm{Y}_{\mathrm{it}}$ : output

$\mathrm{A}_{0}$ : technological factor

$\mathrm{K}_{\mathrm{it}}$ : physical capital

$\mathrm{H}_{\mathrm{it}}$ : human capital

$\mathrm{L}_{\mathrm{it}}$ : labor

$Z$ : set of variables affecting output in a transition economy, including: openness of domestic economy $(F)$, government intervention $(G)$, effect of state-owned enterprises (SOE), and role of agriculture (ARG)

To apply regression model to the study, logarithm of two sides is taken and the function is changed into three following forms:

- Pooled OLS.

$\ln Y_{i t}=a+\beta_{K} \ln K_{i t}+\beta_{H} \ln H_{i t}+\beta_{L} \ln L_{i t}$

$+\theta_{F} F_{i t}+\theta_{G} G_{i t}+\theta_{S O E} S O E_{i t}+\theta_{A R G} A R G_{i t}+u_{i t}$

Where:

$a, \beta$ and $\theta$ : coefficients containing the effects of exogenous variables

$\mathrm{u}_{\mathrm{it}}$ : error term representing impacts of ignored variables

- Fixed effects model - FEM

$\ln Y_{i t}=a+a_{i}+\beta_{K} \ln K_{i t}+\beta_{H} \ln H_{i t}+\beta_{L} \ln L_{i t}$

$+\theta_{F} F_{i t}+\theta_{G} G_{i t}+\theta_{S O E} S O E_{i t}+\theta_{A R G} A R G_{i t}+u_{i t}$

Where: 
$a_{i}$ : fixed quantity for each province, covering features of province i.

- Random effects model - REM

$$
\begin{aligned}
& \ln Y_{i t}=a+a_{i}+\beta_{K} \ln K_{i t}+\beta_{H} \ln H_{i t}+\beta_{L} \ln L_{i t} \\
& +\theta_{F} F_{i t}+\theta_{G} G_{i t}+\theta_{S O E} S O E_{i t}+\theta_{A R G} A R G_{i t}+u_{i t}
\end{aligned}
$$

Where:

$a_{i}$ : random error per space unit in compliance with normal distribution, including the following variables :

Dependent variable Y: GDP of provinces/cities at constant prices in 1994, measured by trillion VND

Explanatory variable $\mathrm{H}$ (human capital): All measures of human capital have strengths and weaknesses and reflect different aspects of human capital. However, due to difficulties in data collection, the authors employ average schooling years of laborers to measure human capital. This measure is commonly employed in such studies that analyze economic growth in different economic sectors and countries as Cravo \& Soukiazis (2009) and Trần et al. (2007).

Laborers are categorized into six groups in terms of achieved education which is similar to the way specified in Vietnam Education Laws (2005): (i) No education (illiteracy); (ii) Literacy but no completion of primary education; (iii) Completion of primary education; (iv) Completion of junior high school education; (v) Completion of senior high school education; and (vi) Completion of undergraduate and graduate education. The average schooling years is calculated by formula 4 :

$$
S=\frac{\sum_{j=0}^{5}\left(L_{j} \sum_{j=0}^{5} T_{j}\right)}{\sum_{j=0}^{5} L_{j}}
$$

Where:

$\mathrm{S}$ : average schooling years of laborers

$\mathrm{j}$ : education at each level

$T_{j}$ : average schooling years at each level

$\mathrm{L}_{\mathrm{j}}$ : laborers with education level $\mathrm{j}$ 
Table 1: Detailed Calculations of $\mathbf{H}$

\begin{tabular}{|c|c|c|c|}
\hline $\mathbf{J}$ & Education level & Explanation & $\begin{array}{c}\mathbf{T}_{\mathbf{j}} \\
(\text { years })\end{array}$ \\
\hline 0 & Illiteracy & Concerning laborers who never go to school & 0 \\
\hline 1 & $\begin{array}{l}\text { No completion of } \\
\text { primary education }\end{array}$ & $\begin{array}{l}\text { Concerning laborers who are literate but have yet to } \\
\text { complete primary education }\end{array}$ & 2 \\
\hline 2 & $\begin{array}{l}\text { Completion of primary } \\
\text { education }\end{array}$ & $\begin{array}{l}\text { Concerning laborers who already completed } \\
\text { primary education and stopped going to school }\end{array}$ & 3 \\
\hline 3 & $\begin{array}{l}\text { Completion of junior } \\
\text { high school }\end{array}$ & $\begin{array}{l}\text { Concerning laborers who already completed junior } \\
\text { high school education and stopped going to school }\end{array}$ & 4 \\
\hline 4 & $\begin{array}{l}\text { Completion of senior } \\
\text { high school }\end{array}$ & $\begin{array}{l}\text { Concerning laborers who already completed senior } \\
\text { high school education and stopped going to school }\end{array}$ & 3 \\
\hline 5 & $\begin{array}{l}\text { Completion of } \\
\text { undergraduate and } \\
\text { graduate education }\end{array}$ & $\begin{array}{l}\text { Concerning laborers who complete college and } \\
\text { higher level education }\end{array}$ & 4 \\
\hline
\end{tabular}

$\mathrm{K}$ (physical capital) is measured by the formula : $K_{t}=(1-\delta) K_{t+1}+I_{t}$ where $\mathrm{I}_{\mathrm{t}}$ is annual investment and $\delta$ is depreciation rate. Due to a lack of provincial data before 1996 , the authors employ 1996 GDP in place of the initial physical capital $\mathrm{K}_{0}$, which is also indicated in Trần et al. (2007). To simplify the case, depreciation rate is assumed at $\delta=5 \%$, found in such studies by $\mathrm{Ng} \&$ Leung (2004), Trần et al. (2007), and Whalley \& Zhao (2010).

L (labor) is calculated by the number of people belonging to the working population regardless of their employment status (Lau et al., 1993). The research considers labor force in each province/city as the local working population as defined by Ministry of Labor, War Invalids and Social Affairs.

F (economic openness) is measured by the ratio of FDI to gross investment. $\mathrm{Ng} \&$ Leung (2004) argue that domestic economic openness would contribute to enhance technology level through promoting the import of advanced technologies and managerial experience. Therefore, the research expects a positive relationship between $\mathrm{F}$ and economic growth as found by Nguyễn et al. (2006) and Trần et al. (2007). 
$\mathrm{G}$ (government intervention) is measured by the ratio of public expenditure to GDP. The impact of public expenditure on economic growth is commonly positive. Yet, Barro (1997) maintains that government intervention distorts the market and hinders technological advancement. According to Rahn (1986), the increase in public expenditure hinders the growth if it exceeds the limit, whereas studies conducted in Vietnam by Phạm (2008) and Hoàng et al. (2010) reveal a negative coefficient of G (-). Hence, this research expects a negative relationship between $\mathrm{G}$ and economic growth.

SOE (effects of state-owned enterprises) is calculated by the share of public sector in total industrial output. Trần et al. (2007) argues that state-owned enterprises are slow to adopt technological advances and even face difficulties in integrating into the market mechanism. Word Bank (2012) indicates that SOEs in Vietnam use ineffectively various resources, which shows itself in capital productivity: the sales to capital ratio of SOEs in 2000 were 1.6 compared to the average of 8.8 for the manufacturing sector. This gap rose to 1.1 compared with 21.0 in 2009. A negative relationship between SOE and economic growth is thus expected, which is also confirmed by $\mathrm{Ng}$ \& Leung (2004) and Trần et al. (2007).

ARG (role of agriculture in the economy) is measured by the share of agriculture (including farming, forestry and fishery) in GDP. According to $\mathrm{Ng} \&$ Leung (2004), provinces/cities that heavily rely on agricultural production have less opportunity to increase productivity than those which rely on industrial production. Trần et al. (2007) also show that a decrease in this share will boost economic growth. The relationship between ARG and economic growth is therefore expected to be negative.

\section{METHODOLOGY}

The study employs quantitative research method with the support of Stata 11 to analyze the relationship between human capital and economic growth in SCV coastal provinces between 2000-2011. Balanced panel data of 8 provinces/cities are employed and aggregated from GSO statistics (GDP by economic sectors, investment by sources, expenditures of local budget, and industrial value by ownership at constant 1994 prices) and Ministry of Labor, War Invalids and Social Affairs (working population by education level) in the period 2000-2011. 


\section{RESULTS AND DISCUSSION}

a. Statistical Description of the Variables in the Model:

Table 2 : Statistical Description of the Variables

\begin{tabular}{ccccccccc}
\hline & Obs. & Mean & Median & Max & Min & Std. Dev & Skewness & Kurtosis \\
\hline Y & 96 & 5290,44 & 4607,888 & 13370,36 & 1252,342 & 2947,537 & 0,8102 & 2,9068 \\
K & 96 & 7224,635 & 6041,463 & 19708,64 & 1475,895 & 4123,153 & 0,8619 & 3,1121 \\
L & 96 & 536990 & 545357,5 & 852900 & 216847 & 180974,4 & $-0,1237$ & 1,8820 \\
H & 96 & 6,7652 & 6,4454 & 9,6300 & 5,5772 & 1,1012 & 1,5900 & 4,5316 \\
F & 96 & 0,0671 & 0,04 & 0,35 & 0 & 0,0666 & 1,6650 & 6,1693 \\
G & 96 & 0,2592 & 0,235 & 0,5 & 0,13 & 0,0895 & 0,8580 & 3,0733 \\
SOE & 96 & 0,3917 & 0,37 & 0,91 & 0,09 & 0,1969 & 0,2631 & 2,3276 \\
ARG & 96 & 0,2943 & 0,32 & 0,52 & 0,03 & 0,1285 & $-0,5818$ & 2,4212 \\
\hline
\end{tabular}

Source: Analytical results from Stata 11

Table 2 discloses the difference in mean and median values of variables $Y, K, L, G$, SOE and ARG is not great and the values of skewness and kurtosis are fairly evenly and centrally distributed. This reveals a quite even growth in SCV coastal provinces. However, the results show a fairly large difference between the minimum and maximum values, i.e. a difference in public expenditure and the share of agriculture in GDP among the provinces/cities. It is worth noting that shares of SOEs in industrial output differ widely over provinces: Quảng Ngãi comes up with the highest SOE value, up to $91 \%$ (subject to the contribution of Dung Quất Oil Refinery) compared to the lowest level of 9\% found in Bình Định.

The values of $\mathrm{H}$ in Table 2 suggest that the data have a right-skewed distribution and central tendency of the data is a pointed polygon with two narrow tails. This implies that human capital of most provinces/cities is higher than the average human capital of the whole region, and there are huge differences in human capital among provinces.

$\mathrm{F}$ value reveals a fairly large difference between the maximum value, 35\% (Phú Yên) and the minimum one, 0\% (Bình Thuận). Approximately equal mean and median values, values of skewness and kurtosis in a right-skewed distribution, and data central tendency taking a shape of narrow-tailed pointed polygon suggest a huge difference in FDI attraction among provinces/cities. 
Table 3: Correlation Matrix of the Variables in the Model

\begin{tabular}{ccccccccc}
\hline & $\mathbf{Y}$ & $\mathbf{K}$ & $\mathbf{L}$ & $\mathbf{H}$ & $\mathbf{F}$ & $\mathbf{G}$ & SOE & ARG \\
\hline Y & 1 & & & & & & & \\
K & 0,9444 & 1 & & & & & & \\
L & 0,4329 & 0,3708 & 1 & & & & & \\
H & 0,4949 & 0,5181 & $-0,1629$ & 1 & & & & \\
F & 0,1363 & 0,1457 & $-0,0501$ & 0,1676 & 1 & & & \\
G & $-0,2652$ & $-0,1630$ & $-0,4283$ & 0,0487 & 0,1516 & 1 & & \\
SOE & $-0,2785$ & $-0,2761$ & $-0,5048$ & 0,2054 & $-0,171$ & 0,1009 & 1 & \\
ARG & $-0,701$ & $-0,6992$ & 0,0316 & $-0,8187$ & $-0,2535$ & 0,1043 & $-0,0858$ & 1 \\
\hline
\end{tabular}

Source: Analytical results from Stata 11

Table 3 reveals no multicollinearity between variables, and particularly, Y shows a high positive relationship with $\mathrm{K}$ due to the method of calculating $\mathrm{K}$. Notably, $\mathrm{Y}$ reveals a highly negative correlation with $A R G$, indicating that a decrease in the share of agriculture may result in an increase in economic growth. $\mathrm{L}$ and $\mathrm{H}$ show a positive linear correlation with the dependent variable $\mathrm{Y}$ with coefficient $\mathrm{r}$ being 0.4329 and 0.3708 respectively, confirming a relationship between the quantity and education level of laborers and economic growth. However, $\mathrm{L}$ and $\mathrm{H}$ have a very weak negative correlation with $\mathrm{r}$ equal to -0.1629 , implying that there exists no distinctive relationship between the quantity and quality of labor force.

\section{b. Estimation and Regression Analysis:}

\section{Selection of Appropriate Regression Model}

The results from the pooled OLS indicate that the explanatory variables $\ln \mathrm{K}, \ln \mathrm{L}$, $\mathrm{G}$, SOE, and ARG are statistically significant; however, $\ln \mathrm{H}$, characterizing human capital's impact and noted with positive estimated coefficients, is not significant. The test results reveal an existence of heteroskedasticity and autocorrelation.

The regression results of the FEM and REM in Table 4 demonstrate that most of the estimated coefficients are statistically significant. Specifically, estimated coefficients of $\operatorname{lnH}$ in both models are positive and insignificant in REM. 
Table 4: Regression Results of FEM and REM

\begin{tabular}{|c|c|c|}
\hline \multirow{2}{*}{$\begin{array}{c}\text { Dependent variable: } \ln Y \\
\text { Explanatory variable }\end{array}$} & \multicolumn{2}{|c|}{ Regression model } \\
\hline & FEM & REM \\
\hline $\ln K$ & $\begin{array}{c}0,5325 \\
(9,99)^{* * *}\end{array}$ & $\begin{array}{c}0,7318 \\
(14,20)^{* * *}\end{array}$ \\
\hline $\ln L$ & $\begin{array}{c}0,6140 \\
(5,65)^{* * *}\end{array}$ & $\begin{array}{c}0,1518 \\
(2,59)^{* * *}\end{array}$ \\
\hline $\ln \mathrm{H}$ & $\begin{array}{l}0,4251 \\
(1,86)^{*}\end{array}$ & $\begin{array}{l}0,0451 \\
(0,28)\end{array}$ \\
\hline F & $\begin{array}{c}0,5053 \\
(3,49)^{* * *}\end{array}$ & $\begin{array}{l}-0,0501 \\
(-0,23)\end{array}$ \\
\hline G & $\begin{array}{c}-0,6144 \\
(-4,15)^{* * *}\end{array}$ & $\begin{array}{c}-0,4382761 \\
(-2,41)^{* *}\end{array}$ \\
\hline SOE & $\begin{array}{l}0,0229 \\
(0,33)\end{array}$ & $\begin{array}{l}-0,1541 \\
(-1,74)^{*}\end{array}$ \\
\hline ARG & $\begin{array}{c}-2,2581 \\
(-6,74)^{* * *}\end{array}$ & $\begin{array}{c}-0,7996 \\
(-2,92)^{* * *}\end{array}$ \\
\hline _cons & $\begin{array}{c}-4,3158 \\
(-3,32)^{* * *}\end{array}$ & $\begin{array}{c}0,3684 \\
(0,50)\end{array}$ \\
\hline $\mathrm{R}^{2}$ & 0,9740 & 0,9543 \\
\hline
\end{tabular}

Note: $* * *, * *$ and $*$ denote significance at $1 \%, 5 \%$ and $10 \%$ respectively. Figures in parentheses are t-statistic.

Source: Analytical results from Stata 11

The results of the Hausman test reject $\mathrm{H}_{0}$, implying that the FEM is more suitable than the REM. The results of FEM test show that it contains heteroskedasticity. The authors address this problem by adjusting estimation of error covariance matrix according to GLS method for panel data processing models (Green, 2008).

Explanation of estimate results in FEM 
Table 5 : Results of FEM with a Robust Option

\begin{tabular}{|c|c|}
\hline $\begin{array}{c}\text { Dependent variable: } \ln Y \\
\text { Explanatory variable }\end{array}$ & $\begin{array}{c}\text { FEM model with Robust option } \\
\text { Regression coefficient }\end{array}$ \\
\hline $\ln K$ & $\begin{array}{c}0,5325 \\
(5,75)^{* * *}\end{array}$ \\
\hline $\ln L$ & $\begin{array}{c}0,6140 \\
(3,30)^{* *}\end{array}$ \\
\hline $\ln \mathrm{H}$ & $\begin{array}{c}0,4251 \\
(2,46)^{* *}\end{array}$ \\
\hline F & $\begin{array}{c}0,5053 \\
(3,19)^{* *}\end{array}$ \\
\hline $\mathrm{G}$ & $\begin{array}{c}-0,6144 \\
(-2,63)^{* *}\end{array}$ \\
\hline SOE & $\begin{array}{c}0,0229 \\
(0,20)\end{array}$ \\
\hline ARG & $\begin{array}{c}-2,2581 \\
(-3,48)^{* * *}\end{array}$ \\
\hline _cons & $\begin{array}{c}-4,3158 \\
(-2,50)^{* *}\end{array}$ \\
\hline $\mathrm{R} 2$ & 0,9740 \\
\hline
\end{tabular}

Note: $* * *, * *$ and $*$ denote significance at $1 \%, 5 \%$ and $10 \%$ respectively. Figures in parentheses are t-statistic.

Source: Analytical results from Stata 11

Results in Table 5 suggest that most explanatory variables affect economic growth:

The human capital represented by the average number of schooling years has explained the economic growth of the SCV province/cities with a positive estimation coefficient as expected and a high value of 0.43 , ranked behind other factors like capital, labor and FDI. This implies that if all other factors remain constant, a $1 \%$ increase in the average number of schooling years will increase the output by $0.43 \%$ /year. Average schooling years of laborers in SCV province/cities vary from 5.6 
to 9.7 years, i.e. human capital greatly affects economic growth, especially in such provinces/cities where the average schooling years are low as Ninh Thuận and Bình Thuận. For instance, the average number of schooling years in Đà Nẵng City is 6, and if this increases by 1 year, i.e. $17 \% \quad\left(\frac{1}{6} 100 \%=11 \%\right)$, GDP will increase $17 * 0,43 \%=7,31 \%$. Similarly, the average number of schooling years in Bình Thuận province is 9 , and if this increases by 1 year, i.e. $11 \%\left(\frac{1}{9} 100 \%=11 \%\right)$, GDP will increase by $11 * 0,43 \%=4,73 \%$.

The research results are quite consistent with previous studies in Vietnam. Particularly, in studies by Nguyễn \& Lê (2004) and Trần et al. (2007), estimated coefficients of human capital are 0.64 and 0.41 respectively. Researches on economic growth in many provinces of other countries also find similar results. According to Cravo \& Soukiazis (2009), human capital affects the growth of Brazilian states with the estimated coefficient being 0.42 while Vidyattama (2010) find that the effect of human capital on Indonesian provincial economic growth has an estimated coefficient of 0.4 .

Physical capital and labor make fairly great contribution to output growth. However, economic growth due to the increase in labor is higher than that caused by increases in physical capital with estimated coefficients of 0.61 and 0.53 respectively. This implies that holding other factors constant, a $1 \%$ increase in labor results in an increase of $0.61 \% / y$ ear in output and a $1 \%$ increase in physical capital produces a 0.53 $\% /$ year increase in output. The results are quite compliant with the findings in the studies on economic growth in Vietnam by Nguyễn \& Lê (2004) and Trần et al. (2007).

The proportion of FDI (F) has not only expected sign but also great impacts on economic growth of the region with positive estimated coefficient being 0.51, ranked just behind the contribution of labor and physical capital. This suggests that FDI is quite effective in the economic growth of SCV provinces/cities and the results are quite similar to the studies by Nguyễn \& Huỳnh (2010) and Nguyễn et al. (2006).

To the authors' amazement, ARG and G are as expected and have a fairly high correlation with the output. The results indicate that negative estimated coefficients are $-2,3$ and $-0,61$ respectively, implying that decreases in agricultural proportion or public 
expenditure would exert profound effects on economic growth of the region. The results are comparatively compliant with those in such studies by Pham (2008) and Hoàng et al. (2010).

Finally, SOE (share of SOEs in industrial value) produces statistically insignificant results, and sign of its estimated coefficient is not as expected. It is likely that the SOEs share is not an appropriate index that represents transition economies of SCV provinces/cities, as confirmed by Trần et al. (2007).

\section{CONCLUSIONS}

To examine and analyze the effects of human capital and other macroeconomic variables on economic growth of SCV coastal provinces between 2000 and 2011, the study employed a neoclassical growth model based on the Cobb-Douglas production function suggested by $\mathrm{Ng} \&$ Leung (2004).

The results indicate that compared to the other two proposed models (pooled data regression model and random effects model), fixed effects model is the most appropriate, allowing the following conclusions:

First, the FEM allowed the study to demonstrate the role of human capital in economic growth in SCV costal provinces in the 2000-2011 periods. The regression results show that the contribution of human capital is equal to the average schooling years of laborers with estimated effect of nearly $0.43 \%$ per one-percent increase of the average schooling years. As the average schooling years of laborers in these provinces ranges from about 5.6 to 9.7 years, an increase by one schooling year will increase the region's GDP by $11 \%-17 \%$ /year.

Although the study does not specify any particular type of education that affects economic growth but the estimation of human capital shows that SCV provinces/cities should adopt sound policies to increase the average number of schooling years, thereby helping increase the output. Specifically, policies on development and improvement in the quality at all levels of education, construction of schools and study facilities, innovation of teaching methods, and offer of scholarship, etc. are much needed. Additionally, there should be policies to attract, employ, and train the labor force in necessary skills.

The World Bank report "Vietnam - High Quality Education for All by 2020" (2011) suggests that enrollment rates and completion of general education levels depend on: (i) learners' characteristics (permanent household, parental education 
level.); (ii) teachers' characteristics (education level, experience, pedagogical practices); (iii) schools' characteristics (equipment, learning and teaching materials, infrastructure, support services); and (iv) funding (contributions, level of school supply, etc.).

The report also points out that there should be policies to: (i) improve the school resource / schooling costs such as development of satellite schools, tuition policy, cash support and early childhood and complementary school services; (ii) improve school resources concerning assessment of school quality, length of education, class size; (iii) to improve the quality of school management with a focus on principal management and community involvement; and (iv) enhance the quality of teachers and pedagogical practices with orientation toward the qualification of teachers and principals as well as teacher's competence, pedagogical activities and teaching credentials.

Additionally, Trần et al. (2011) suggest enhancing economic growth and narrowing the gap between provinces/cities, promoting achievements of primary education universalization, and trying to achieve universal secondary education. Moreover, provinces/cities should not focus too much on fostering new school (including universities) construction, but pay more attention to the development of the education system in accordance with local and regional characteristics of demand for labor, and try to apply preferential treatments to attract well trained and skilled employees.

Next, the estimated results suggest that the SCV, compared to other regions, makes better use of capital and labor force. Thus, the provinces should adopt sound policies to well attract, allocate and use various capital sources.

Last, macroeconomic variables that represent a transition economy show that the region gains a fairly rapid and dynamic development by employing effectively FDI and reducing agricultural share in GDP. Hence, building and developing infrastructure to stimulate FDI are required. Furthermore, the SCV, with its geographical advantages, could develop manufacturing and service sectors, especially in provinces with high agricultural output such as Ninh Thuận, Bình Định and Phú Yên.

Obviously, investment in and development of education accumulate and enhance human capital which benefits the community through various channels and especially helps enhance labor productivity. For such reasons, education development is a feasible way to boost economic growth in Vietnam in general and SCV coastal provinces in particular. 


\section{SHORTCOMINGS AND RECOMMENDATION ON FURTHER STUDIES}

This study reveals the following limitations: (i) The application of neoclassical growth model with extended Cobb-Douglas production function to a few macroeconomic variables partly reflects economic growth in SCV coastal provinces/cities; (ii) the study employs only one measure of human capital (the average number of schooling years) instead of many others; (iii) one long-standing problem with empirical studies lies in the quality of statistics of Vietnam's economy; and (iv) empirical researches on economic development often need long-term time series, whereas the study can only address the data of a 12-year period.

These shortcomings can be remedied by further studies with an adoption of better efficient measurement of human capital, such as education costs and laborer's income and other more complicated and closer-to-reality models, applicable to SCV coastal provinces in particular and to other provinces/cities in general

\section{References}

Barro, R.J. (1991), "Economic Growth in a Cross Section of Countries", NBER Working Paper Series, 3210.

Barro, R.J. (1997), "Determinants of Economic Growth: A Cross-Country Empirical Study", NBER Working Paper Series, 5698.

Barro, R.J. \& J.W. Lee (1993), "International Comparisons of Educational Attainment", NBER Working Paper Series, 4349.

Barro, R.J. \& J.W. Lee (2010), "A New Data Set of Educational Attainment in the World 19502010", NBER Working Paper Series, 15902.

Barro, R.J. \& X. Sala-i-Martin (1995), Economic Growth, Cambridge, MA: MIT Press.

Coulombe, S. \& J.A. Tremblay (2001), "Human Capital and Regional Convergence in Canada", Journal of Economic Studies, 28 (3).

Cravo, T.A. \& E. Soukiazis (2009), "Educational Thresholds and Economic Growth: Empirical Evidence from Brazilian States", INFER Working Paper 2009.1.

Green, W.H. (2008), Econometric Analysis, New York University.

GSO (2012), "Báo cáo điều tra Lao động Việc làm Việt Nam năm 2011", available at $<$ http://www.gso.gov.vn/default.aspx?tabid=512\&idmid =5\&ItemID=12540>.

Hoàng Thị Chinh Thon, Phạm Thị Hương \& Phạm Thị Thủy (2010), "Tác động của chi tiêu công tới tăng trưởng kinh tế tại các địa phương ở Việt Nam", Trung tâm nghiên cứu kinh tế và chính sách (Vietnam Center for Economic and Policy Research), available at 
$<$ http://vepr.org.vn/533/ebook/nc-19-tac-dong-cua-chi-tieu-cong-toi-tang-truong-kinh-te-tai-cacdia-phuong-o-viet-nam/25115.html>.

Judson, R. (1995), "Do Low Human Capital Coefficients Make Sense? A Puzzle and Some Answers", Finance and Economics Discussion Series, Board of Governors of the Federal Reserve System, 96-13.

Laroche, M. \& M. Mérette (1999), "On the Concept and Dimensions of Human Capital in a Knowledge-Based Economy Context", Canadian Public Policy - Analyse de Politiques, 25(1).

Lau, L.J, D.T. Jamison, S.C. Liu \& S. Rivkin (1993), "Education and Economic Growth: Some Cross-Sectional Evidence from Brazil”, Journal of Development Economics, 41: 45-70.

Leeuwen, Bas van (2004), "Literature on the Relation between Human Capital and Economic Growth: Definitions and Problems", available at $<$ http://www.moj.gov.vn/vbpq/Lists/Vn\%20bn\%20php\%201ut/View_Detail.aspx?ItemID=1814 $8>$.

Li, H. \& H. Liang (2009), "Health, Education, and Economic Growth in East Asia" available at $<$ http://www.perpustakaan.depkeu.go.id/FOLDERJURNAL/Health,_education,.pdf $>$.

Lucas, R.E. (1988), "On the Mechanics of Economic Development", Journal of Monetary Economics, 22: 3-42.

Mankiw, N. G., D. Romer \& D. Weil (1992), "A Contribution to the Empirics of Economic Growth", NBER Working Paper Series, 3541.

Martín, M.G. \& A.A. Herranz (2004) "Human Capital and Economic Growth in Spanish Regions", International Advances in Economic Research, 10(4): 257-264.

Mulligan, C. \& X. Sala-i-Martin (1997), “A Labor Income Based Measure of Human Capital”, Japan and the World Economy, 9: 159-191.

Ng., Y.C. \& C.M. Leung (2004), "Regional Economic Performance in China: A Panel Data Estimation", RBC Papers on China, Hong Kong Baptist University, available at $<$ https://net2.hkbu.edu.hk/ ied/publications/cp/CP200204.pdf $>$, retrieved on April 4, 2012.

Nguyễn Phú Tụ \& Huỳnh Công Minh (2010), "Mối quan hệ giữa đầu tư trực tiếp nước ngoài với tăng trưởng kinh tế của Việt Nam”, Phát triển Kinh tế, No.239.

Nguyễn Thị Tuệ Anh \& Lê Xuân Bá (2006), "Chất lượng tăng trưởng kinh tế - Một số đánh giá ban đầu cho Việt Nam", Quản lý Kinh tế, No.6.

Nguyễn Thị Tuệ Anh, Vũ Xuân Nguyệt Hồng, Trần Toàn Thắng \& Nguyễn Mạnh Hải (2006), 'Tác động của đầu tư trực tiếp nước ngoài tới tăng trưởng kinh tế ở Việt Nam”, Viện Kinh tế Trung ương, available at <http://www.ciem.org.vn/home/vn/upload/info/attach/1163486 4501560_RRFDITang_truong_KTvietnamese_233.pdf $>$. 
Permani, R. (2008), "Education as a Determinant of Economic Growth in East Asia: Historical Trends and Empirical Evidences (1965-2000)", available at $<$ http://apebhconference.files.wordpress.com/2009/09/permani-20081.pdf>.

Permani, R. (2009), "The Role of Education in Economic Growth in East Asia: A Survey", AsianPacific Economic Literature, 23(1): 1-20.

Phạm Thế Anh (2008), "Chi tiêu chính phủ và tăng trưởng kinh tế: Khảo sát lý luận tổng quan", Trung tâm Nghiên cứu kinh tế và chính sách (Vietnam Center for Economic and Policy Research), available at <http://vepr.org.vn/533/ebook/nc-02-chi-tieu-chinh-phu-va-tang-truongkinh-te-khao-sat-ly-luan-tong-quan/25132.html>.

Phạm Thế Anh (2008), "Phân tích cơ cấu chi tiêu chính phủ và tăng trưởng kinh tế ở Việt Nam", Trung tâm Nghiên cứu kinh tế và chính sách, (Vietnam Center for Economic and Policy Research), available at <http://vepr.org.vn/533/ebook/nc-03-phan-tich-co-cau-chi-tieu-chinhphu-va-tang-truong-kinh-te-o-viet-nam/25131.html>.

Romer, P.M. (1990), "Human Capital and Growth: Theory and Evidence", NBER Working Series, 3173.

Solow, R.M. (1956), "A Contribution to the Theory of Economic Growth", available at $<$ http://www.econ.nyu.edu/user/debraj/Courses/Readings/Solow.pdf $>$.

Trần Thọ Đạt et al. (2007), "Những nhân tố tác động đến tăng trưởng kinh tế các tỉnh, thành phố Việt Nam giai đoạn 2000-2006", a working paper financed by National Economics University, Hà Nội.

UNDP (2011), "Báo cáo Quốc gia về Phát triển Con người năm 2011", available at $<$ http://www.undp.org.vn/digitalAssets/27/27109_902_UNDP_Final_low_res_file_VN_310112. pdf $>$.

Vidyattama, Y. (2010), “A Search for Indonesia's Regional Growth Determinants”, available at $<$ http://muse.jhu.edu/journals/asean_economic_bulletin/summary/v027/27.3.vidyattama.html $>$.

Whalley, J. \& X. Zhao (2010), "The Contribution of Human Capital to China's Economic Growth", NBER Working Paper Series, 16592.

World Bank (2011), "Báo cáo Phát triển Việt Nam 2012", available at <http://wwwwds.worldbank.org/external/default/WDSContentServer/WDSP/IB/2011/12/13/000333037_201 11213004140/Rendered/PDF/659800VIETNAME0elopment0Report02012.pdf>.

World Bank (2012), "Nâng cao chất lượng giáo dục cho mọi người đến năm 2020", available at $<$ http://www-wds.worldbank.org/external/default/

WDSContentServer/WDSP/IB/2012/04/18/000333038_20120418015708/Rendered/PDF/68092 0v20VIETN04017020120Box367913B.pdf $>$. 